CORRECTION

\title{
Correction: Thrombospondin-targeting TAX2 peptide impairs tumor growth in preclinical mouse models of childhood neuroblastoma
}

\author{
Albin Jeanne ${ }^{1,2,3}$, Revital Rattenbach ${ }^{4}$, Itschak Lamensdorf ${ }^{4}$, Laurent Martiny ${ }^{1,2}$, Celine Martin ${ }^{4}$ and Stéphane Dedieu ${ }^{1,2}$ \\ Pediatric Research (2019) 85:734; https://doi.org/10.1038/s41390-019-0329-4
}

Correction to: Pediatric Research (2017) 81: 480-488. https://doi. org/10.1038/pr.2016.242; published online 04 January 2017.

Following publication, the authors of the original version of this article proposed to add the authors: "Revital Rattenbach", "Itschak Lamensdorf", and "Celine Martin". The author list of this article should therefore be considered to be as follows:

Albin Jeanne ${ }^{1,2,3}$, Revital Rattenbach ${ }^{4}$, Itschak Lamensdorf ${ }^{4}$, Laurent Martiny ${ }^{1,2}$, Celine Martin ${ }^{4}$ and Stéphane Dedieu ${ }^{1,2}$
${ }^{1}$ Universite de Reims Champagne-Ardenne, UFR Sciences Exactes et Naturelles, Reims, France

${ }^{2}$ CNRS UMR 7369, Matrice Extracelfulaire et Dynarnique Cellulaire, MEDyC, Reims, France

${ }^{3}$ SATT Nord, Lille, France

${ }^{4} 4 \mathrm{P}$-Pharma, Lille, France

The authors would like to apologise for this error. This has not been corrected in the PDF or HTML of this article.

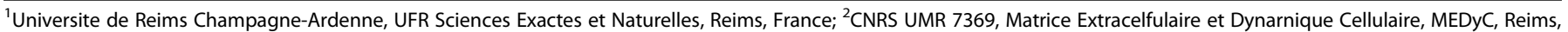
France; ${ }^{3}$ SATT Nord, Lille, France and ${ }^{4} 4 \mathrm{P}$-Pharma, Lille, France

Correspondence: Stéphane Dedieu (stephane.dedieu@univ-reims.fr)

Published online: 14 February 2019 